\title{
AN ASSESSMENT OF A CORPORATIZED AIRPORT COMPANY REVENUE STREAMS: PART 2 - AIRPORTS OF THAILAND NON- AERONAUTICAL REVENUES
}

\author{
Glenn Baxter ${ }^{1}$, Panarat Srisaeng ${ }^{2}$ \\ 1,2 School of Tourism and Hospitality Management, Suan Dusit University, Huahin Prachaup Khiri Khan, \\ Thailand, 77110
}

Received 19 February 2021; accepted 20 August 2021

\begin{abstract}
Using a qualitative longitudinal case study research approach, this study examines Airports of Thailand PLC (AOT) non-aeronautical revenues from 2005 to 2019. The Airports of Thailand PLC has three major non-aeronautical revenue streams. The non-aeronautical revenues are comprised of concession revenues, office and state property rents, and service revenues. Non-aeronautical revenues are the second highest source of revenue for Airports of Thailand (AOT) accounting for slightly under half of the company's annual revenue. The case study revealed that non-aeronautical revenues grew by $393.92 \%$ over the study period. The most significant growth in the non-aeronautical revenue stream came from service charge revenues, which increased by $831.82 \%$ from 2005 to 2019. The growth in the Airports of Thailand PLC non-aeronautical revenues can be attributed to the substantial growth in passenger volumes and aircraft movements during the study period.
\end{abstract}

Keywords: airports, Airports of Thailand PLC (AOT), case study, corporatized airport business model, non-aeronautical revenues.

\section{Introduction}

The generation of revenue is a vital output of all industries, whether they may be in the service industry or manufacturing industries. The global airport industry's output value is measured from the generation of both aeronautical and non-aeronautical revenues. Airport revenue may be defined "as the income generated from the air traffic operations, terminal building which is charged or priced from the customers for the use of the airport utilities" (Senguttuvan, 2007).

The liberalization of air transport markets introduced new dynamics that has increased the complexity in the airport industry (Jiminez et al., 2014). Liberalization has also resulted in many airports being privatized or commercialized (Forsyth et al., 2016; Lei and Pagliari, 2016; Vogel, 2019). The commercialization of airports that occurred throughout the 1970s and 1980s and the airport privatization process in the 1990s have led to the emergence of a more competitive and market-oriented airport industry (Castro and Lohmann, 2014).

In pursuing commercial strategies airport owners and operators typically need to decide between two alternative strategies. Airports can follow the traditional airport model which

${ }^{1}$ Corresponding author: g_glenn.bax@dusit.ac.th 
is one where airports view their primary task as being able to satisfy the basic and essential requirements of passengers, airlines, air freight forwarders and other direct customers or users. This is the strategy that has been traditionally followed by governmentowned airports especially if operated by a government department such as the Ministry of Transport (Doganis, 2005, pp.112-113).

The alternative strategic option is that of the commercial airport model (Abeyratne, 2009; Doganis, 2005; Graham and Morrell, 2017). The objective of the commercial airport model is to optimize income from any appropriate activity at the airport. Such a strategy means that the airport authority regards the airport as a business opportunity which not only serves its direct and traditional customers for example, airlines, passengers, and air cargo shippers - but also a wider range of potential customers including airport and airline staff, visitors, people meeting passengers, residents in the surrounding communities as well as local businesses and industries (Doganis, 2005). Under such a strategy, airports optimize revenues, irrespective of whether they are generated through aeronautical revenues or non-aeronautical revenues sources (Abeyratne, 2014).

Airport commercialization results in the transformation of a public utility into a commercial enterprise and includes the adoption of more businesslike management practices (Freestone, 2009). One such airport company that has evolved from being a public utility into a fully commercialized enterprise is Thailand-based Airports of Thailand PLC (AOT). The aim of this study is to examine the development of and the types of non-aeronautical revenue sources of a major airport company that has adopted a commercial business model and who operates multiple airports as part of their business portfolio. The company selected for the study is Airports of Thailand PLC (AOT). The company manages and operates six major airports in Thailand, including Bangkok's Suvarnabhumi Airport, which is a key regional aviation hub (Moh and Lin, 2005). The principal objective of the study is to examine how have Airports of Thailand PLC (AOT) non-aeronautical revenues have grown over the period 2005-2019 following the company's adoption of a corporatized business model. A secondary aim is to examine the annual trends in Airports of Thailand various nonaeronautical revenue sources. A further aim is to identify which non-aeronautical revenue stream has experienced the most significant growth for AOT during the study period.

The remainder of the paper is organized as follows. The literature review is presented in Section 2. The research methodology underpinning the Airports of Thailand PLC (AOT) case study is outlined in Section 3. The case study based on Airports of Thailand PLC is presented in Section 4. The results of the study are presented in the conclusions section of the paper.

\section{Background on Airport Non- Aeronautical Revenues}

Airport income is generated from both aeronautical and traffic-related activities and from non-aeronautical or commercial sources (Halpern and Graham, 2013; Liu, 2016; Yokomi et al., 2017). Following commercialization there has been an increasing importance placed on the generation of non-aeronautical revenues as well as changes in this activity as airports explore new ways to generate funds (Lyon and Francis, 2014). Historically, aeronautical revenues were the principal revenue source for airports (Serebrisky, 2012). However, in recent times, 
non-aeronautical charges have developed into a major revenue source for airports located all around the world (Fu and Yang, 2017; Moulds and Lohmann, 2016). It has been estimated that non-aeronautical revenues on average account for around half of all revenues generated by airports (Fasone et al., 2016).

Revenues from non-aeronautical sources are those revenues received by an airport in consideration for the various commercial arrangements it makes in relation to the granting of concessions, the rental or leasing of premises and land, and free-zone operations. In some instances, such arrangements may apply to those activities that may themselves could be regarded of an aeronautical character (for instance, concessions granted to oil companies to supply aviation fuel and lubricants and the rental of terminal building space or premises to aircraft operators) (International Civil Aviation Organization, 2013a). In addition, the commercialization of the airport industry has increased the importance of airline passengers to the development of airports because these passengers generate large non-aeronautical revenues for airports (Wattanacharoensil et al., 2017).

Concession revenues are those generated by the airport from non-aircraft related commercial activities in the terminal areas and on airport property (Graham, 2009; Zhang et al., 2010). Concession operations include the running or leasing out of shopping concessions of various kinds, car parking and rental, banking, and restaurant/ catering, with terminal concessions and car parking and rental being the most important revenue sources (Zhang and Zhang, 1997). Furthermore, the commercial development occurring at and around airports (Orth et al., 2015 ) is turning airports into urban growth generators as they increasingly become significant employment, shopping, trading, and business destinations (Reiss, 2007).

A relationship exists between airport size and revenue generation sources: larger airports are more capable of exploiting commercial sources and therefore obtain more revenue from this source. In contrast, smaller airports are quite often very reliant upon aeronautical revenues (Betancor and Rendeiro, 2000; Doganis, 2005). In recent years, the development of commercial revenues at airports has been driven by two key factors. Firstly, the evolution of the airport sector from a public utility to a commercialized, and, in some instances, privatized industry that has provided airports with greater freedom, expertise and motivation to exploit the commercial opportunities that exist. Secondly, there has been growing pressure from the airline industry to control airports other principal revenue stream, namely aeronautical charges (Graham, 2009).

The terminal area concessions include all the non-airline users of the airport terminal area. There are often a diversity of concessions and these may include food and beverage concessions, specialty stores and shops, travel services and facilities, personal services, such as, hairdressers and a shoe-shine stand, amusements (movies, TV rooms, aircraft observation desks), display advertising, or outside terminal concessions (these include car parking, ground transportation services, hotels, and motels) (Young and Wells, 2011).

\section{Research Methodology}

\subsection{Research Method}

The research undertaken in this study was underpinned by a qualitative longitudinal research design (Derrington, 2019; Hassett 
and Paavilainen-Mäntymäki, 2013; Neale, 2018). The study was also exploratory in nature (Stebbins, 2001; Yin, 2018). Exploratory research is a methodological approach that is principally focused on discovery and with the generation or development of theory (Jupp, 2006). When conducting case study research, the goal is to expand and build theories rather than perform statistical analysis to test a certain hypothesis (Rahim and Baksh, 2003).

\subsection{Data Collection}

The data collected for the study was sourced from Airports of Thailand PLC (AOT), and included the airport's annual reports, and company materials available on the internet. These documents were the sources of the study's case evidence. A comprehensive source of the leading airport-related journals and airport industry magazines was also conducted. The study also included a search of the SCOPUS and Google Scholar databases. The key words used in the database searches included "Airports of Thailand PLC (AOT) non-aeronautical revenues", "Airports of Thailand PLC (AOT) concession revenues”, "Airports of Thailand PLC (AOT) office and state property rents", and "Airports of Thailand PLC (AOT) service revenues”.

Secondary data was therefore used in the study. The study followed Yin's (2018) three principles of data collection when conducting case study research: the use of multiple sources of case evidence, creation of a database on the subject, and the establishment of a chain of evidence.

\subsection{Data Analysis}

The data collected for the case study was examined using document analysis.
Document analysis is a research technique that is quite extensively used in case study research. Document analysis focuses on the information and data that is contained in formal documents and company records (Oates, 2006; Ramon Gil-Garcia, 2012). In accordance with the recommendations of (Scott, 2014) and (Scott and Marshall, 2009) all the documents collected for the study were examined for their authenticity, credibility, representativeness, and meaning.

The study's document analysis comprised six phases. The first phase involved planning the types and required documentation and ascertaining their availability for the study. In the second phase, the data collection involved sourcing the documents from Airports of Thailand (AOT). This phase also involved the development and implementation of a scheme for managing the documents collected for the study. The documents were carefully examined to assess their authenticity, credibility and to identify any potential bias in the third phase of the document analysis process. In the fourth phase, the content of the collected documents was carefully examined, and the key themes and issues were identified and recorded. The fifth phase involved the deliberation and refinement to identify any difficulties associated with the documents, reviewing sources, as well as exploring the documents content. In the sixth and final phase, the analysis of the data was completed (O’Leary, 2004).

Following the recommendation of (Yin, 2018), all the gathered documents were downloaded and stored in a case study database. All the documents collected for the study were in English. Each document was carefully read, and key themes were coded and recorded (Baxter, 2020). 


\section{Results}

\subsection{Airports of Thailand PLC: A Brief Overview}

Airports of Thailand Public Company Limited (AOT), is a corporatized state enterprise based in Bangkok, Thailand. AOT is a public limited company. The Ministry of Finance has been its largest single shareholder holding a 70 per cent stake, with the remaining 30 per cent held by institutional and retail investors (International Civil Aviation Organization, 2013b). AOT's principal business activities are the management, operations, and development of airports. AOT manages 6 major airports located around Thailand: Don Mueang, Phuket, Chiang Mai, Hat Yai, Chiang Rai and Bangkok's Suvarnabhumi International Airport, all of which accommodate both domestic and international flights. AOT is also responsible for the construction, maintenance, and operation of Thailand's major airports (Asian Development Bank, 2014).

\subsection{Airports of Thailand PLC Annual Non- Aeronautical Revenues}

The Airports of Thailand Public Company Limited (AOT) (hereafter AOT) annual nonaeronautical revenues and the associated yearon-year change from 2005 to 2019 are presented in Figure 1. As can be observed in Figure 1, AOT's annual non-aeronautical revenues have largely exhibited an upward growth trajectory reflecting the company's ability to earn greater non-aeronautical revenues. This trend is demonstrated by the year-on-year percentage change line graph, which is more positive than negative, that is, all values are above the line. Figure 1 shows that there was a spike in the annual non-aeronautical revenues in 2009 , when such revenues increased by $33.89 \%$ on the 2008 levels. This was the largest single annual increase in non-aeronautical revenues recorded throughout the study period. The second highest single annual increase in nonaeronautical revenues was recorded in 2013 (+23.13\%). The lowest annual change in AOT's non-aeronautical revenues occurred in 2019, when the company's non-aeronautical revenues increased by $4.6 \%$ on the 2018 levels (Figure 1).

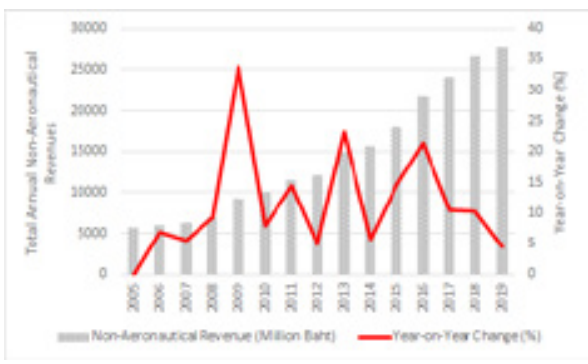

Fig. 1.

Airports of Thailand Public Company Limited Annual non-aeronautical Revenues and Year-on-year Change: 2005-2019

Source: data derived from Airports of Thailand Public Company Limited (2006-2017, 2018b, 2019, 2020) 
An important metric used in the airport industry is the annual non-aeronautical revenues as a share of total operating revenue (Airports Council International, 2012). Figure 2 presents AOT's annual non-aeronautical revenues as a share of total revenues from 2005 to 2019 . As can be seen in Figure 2, the non-aeronautical revenues as a share of total revenues have fluctuated throughout the study period. The lowest share occurred in 2008, when nonaeronautical revenues accounted for $31.8 \%$ of total revenues. The highest share occurred in 2019, when non-aeronautical revenues accounted for $44.2 \%$ of total revenues. Also, as can be observed in Figure 2, there has been an upward trend in non-aeronautical revenues as a share of total revenues from 2012 to 2019 , reflecting the greater commercial activities of the company. The largest single increase in non-aeronautical revenues as a share of total revenues was recorded in 2009, when the non-aeronautical revenues share increased by $37.02 \%$ on the previous year level (Figure 2). The smallest decrease in the annual non-aeronautical revenues as a share of total revenues occurred in 2006, when the non-aeronautical revenue share decreased by $2.11 \%$ on the 2005 level (Figure 2). Over the period 2005 to 2019, AOT's non-aeronautical revenues as a share of total revenues averaged around $40.0 \%$.

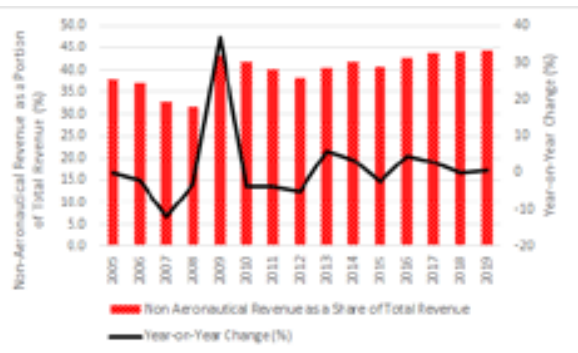

Fig. 2.

Airports of Thailand Public Company Limited Annual non-aeronautical Revenues as a Portion of Total Revenues and Year-on-year Change: 2005-2019

Source: data derived from Airports of Thailand Public Company Limited (2006-2017, 2018b, 2019, 2020)

Another important metric used in the airport industry is the annual non-aeronautical revenues per enplaned passenger (Airports Council International, 2012). Figure 3 presents AOT's annual non-aeronautical revenues per enplaned passenger and the year-on-year change (\%) from 2005 to 2019. As can be observed in Figure 3, AOT's annual non-aeronautical revenues per enplaned passenger have increased from a low of THB 119.02/enplaned passenger in
2005 to a high of THB 208.33/ enplaned passenger in 2019, reflecting the strong growth in non-aeronautical revenues over this period. Over the study period, the non-aeronautical revenues per enplaned passenger predominantly displayed an upward trend. This is demonstrated by the year-on-year percentage change line graph, which is more positive than negative, that is, more values are above the line than below. The largest single annual increase in 
AOT's annual non-aeronautical revenues per enplaned passenger was recorded in 2009, when there was a $55.88 \%$ increase on the previous year's level. The lowest annual decrease in AOT's annual non-aeronautical revenues per enplaned passenger occurred in 2006 , when there was a decline of $2.52 \%$ on the previous year's annual non-aeronautical revenues per enplaned passenger levels (Figure 3).

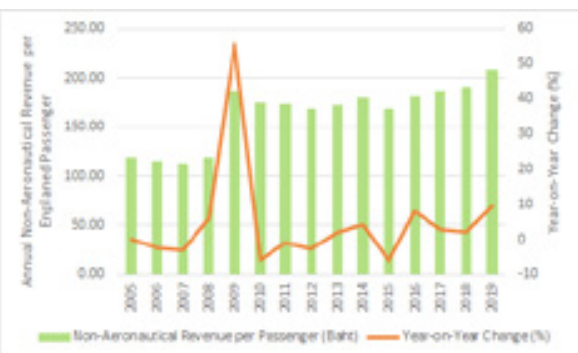

Fig. 3.

Airports of Thailand Public Company Limited Annual non-aeronautical Revenues per Enplaned Passenger and Year-on-year Change: 2005-2019

Source: data derived from Airports of Thailand Public Company Limited (2006-2017, 2018b, 2019, 2020)

\subsection{AOT's Concession Revenues}

AOT's annual concession revenues and the year-on-year change for the period 2005 to 2019 are presented in Figure 4. A concession is the right of a firm to operate a certain commercial activity at an airport, commonly on an exclusive basis and typically at a specified location within the airport (International Civil Aviation Organization, 2013a). Concession revenues includes the fees that AOT collects from retailers, aircraft refueling services, flight catering, restaurants, parking, advertising, and current exchange lessees are required to pay to AOT (Airports of Thailand Public Company Limited, 2008). The strong growth in concession revenues is demonstrated by the year-on-year percentage change line graph, which are more positive than negative, that is, all values except for one are above the line. Figure 4 shows that AOT's annual concession revenues have increased from THB 3,821.64 million in 2005 to a high of THB 17,500.4 million in 2019, reflecting the strong development in concessions at the airports managed and operated by AOT. The largest single annual increase in concession revenues was recorded in 2009, when they increased by $104.28 \%$ on the previous year levels (Figure 4). The smallest annual increase in commercial revenues occurred in 2019, when the company's commercial revenues increased by $4.61 \%$ on the 2018 levels. Also, as can be seen in Figure 5, there was only one year during the study period when concession revenues decreased on the previous year. This occurred in 2007, when the annual concessions decreased by $51.22 \%$ on the previous year levels. This may have been due to the lower activity levels of the concessionaires during that year (Figure 4). 


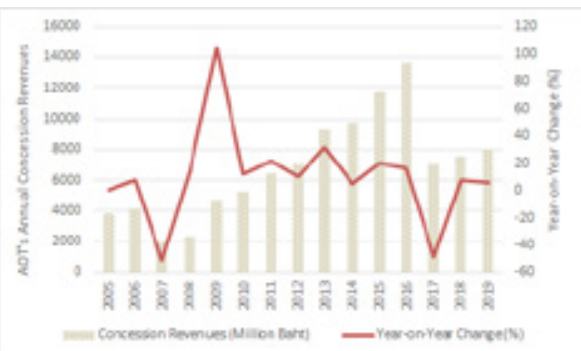

Fig. 4.

Airports of Thailand Public Company Limited Annual Concession Revenues and Year-on-year Change: 2005-2019

Source: data derived from Airports of Thailand Public Company Limited (2006-2017, 2018b, 2019, 2020)

Figure 5 presents AOT's annual concession revenue per passenger and the year-on-year change (\%) from 2005 to 2019. Doganis (2005) has observed that it is important for an airport to measure the revenue generated per enplaned passenger. One passenger enplanement measures the embarkation of a revenue passenger, whether originating, stop-over, connecting or returning (Holloway, 2016). Since most an airport's commercial activities are oriented towards satisfying the requirements of passengers and those accompanying them to the airport, enplaned passenger thus provide a more satisfactory measure of an airport's throughput in the commercial area than work-load units (WLUs) would be (Doganis, 2005). A workload unit
(WLU) is equivalent to one passenger or 100kgs of air cargo (Doganis, 2005; Janić, 2016). As can be observed in Figure 5, the annual concession revenue per passenger has increased from THB 80.7 in 2005 to a high of THB 123.1 in 2019. Figure 5 shows that in 2007 there was a significant decrease in the annual concession revenue per passenger of $54.84 \%$ on the previous year's levels. Figure 5 also shows that there was a very pronounced spike in the annual concession revenue per passenger recorded in 2009 (+ 172.13\%). Despite a decline in passengers, there was a large increase in the concession revenues in 2009 (Figure 5). Throughout the study period, the average annual concession revenue per enplaned passenger was THB 94.2.

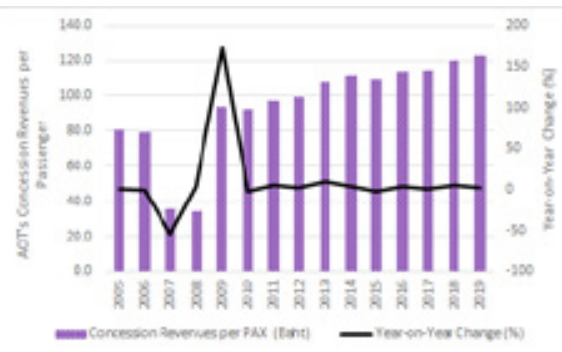

Fig. 5.

Airports of Thailand Public Company Limited Annual Concession Revenues per Enplaned Passenger and Year-on-year Change: 2005-2019

Source: data derived from Airports of Thailand Public Company Limited (2006-2017, 2018b, 2019, 2020) 
Figure 6 presents AOT's annual concession revenue as a portion of total non-aeronautical revenues and the year-on-year change (\%) for the period 2005 to 2019 . As can be observed in Figure 6, AOT's annual concession revenue as a portion of total non-aeronautical revenues has fluctuated throughout the period 2005 to 2019 reflecting the success of the company's concessionaires as well as the annual passenger throughput. The highest annual share of concession revenue as a share of total non-aeronautical revenues was recorded in 2006 (68.52\%), whilst the lowest annual concession revenues as a share of total non-aeronautical revenues occurred in 2007 (31.66 \%) (Figure 6). The largest single annual increase in the annual concession revenue as a share of total non-aeronautical revenues occurred in 2009, when there was a $52.55 \%$ increase on the previous year's share of total non-aeronautical revenues (Figure $6)$. The largest single annual decrease in the annual concession revenue as a share of total non-aeronautical revenues occurred in 2007 , when there was a $53.79 \%$ decrease on the previous year's share of total non-aeronautical revenues (Figure 6). Throughout the period 2005 to 2019, the annual concession revenue as a portion of total non-aeronautical revenue averaged $57.29 \%$. Concession revenues are AOT's most significant source of AOT's annual non-aeronautical revenues.

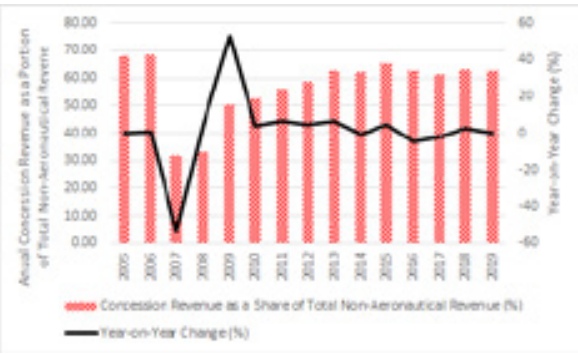

Fig. 6.

Airports of Thailand Public Company Limited Annual Concession Revenues as a Portion of Total nonaeronautical Revenues and Year-on-year Change: 2005-2019

Source: data derived from Airports of Thailand Public Company Limited (2006-2017, 2018b, 2019, 2020)

\subsection{Office and State Property Rents}

Another non-aeronautical revenue source for AOT is the assessment of office and state property rentals at the airports that the company operates and manages. Figure 7 presents AOT's annual office and state property rental revenues and the year-on-year change (\%) over the period 2005 to 2019 . As can be observed in Figure 7, these revenues have increased from a low of THB 953.16 million in 2005 to a high of THB 2,296.46 million in 2019. Figure 7 shows that there was a predominantly an upward trend in this revenue stream over the period 2005 to 2019, with the only exceptions being in 2008, 2010, and 2012, when the annual office and state property rental revenues decreased by $2.88 \%, 4.85 \%$ and $7.28 \%$ on the previous year levels, respectively. The largest single annual increase in AOT's annual office and state property rental revenues occurred in 2007 , when there was a $58.36 \%$ on the 2006 levels (Figure 7). The overall favorable growth trend in AOT's annual office and state property rental revenues indicates that the company is optimizing office rentals at its various airports, and this is developing into an important revenue source. 


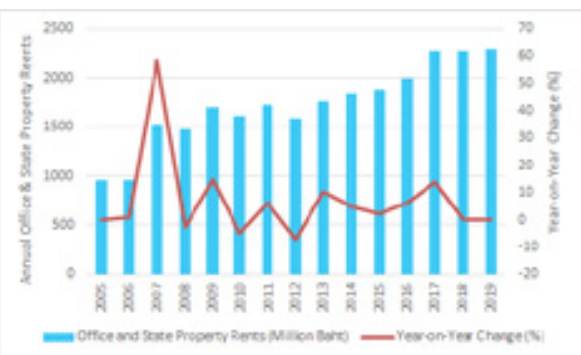

Fig. 7.

Airports of Thailand Public Company Limited Annual Office and State Property Tax Revenues and Year-on-year Change: 2005-2019

Source: data derived from Airports of Thailand Public Company Limited (2006-2017, 2018b, 2019, 2020)

AOT's annual office and state property rental revenue as a portion of total non-aeronautical revenues and the year-on-year change (\%) for the period 2005 to 2019 are presented in Figure 8. As can be observed in Figure 8, AOT's annual office and state property rental revenue as a portion of total non-aeronautical revenues has oscillated throughout the period 2005 to 2019. The highest annual share of office and state property rental revenue as a share of total non-aeronautical revenues were recorded in 2007 (23.99\%), whilst the lowest annual office and state property rental revenue as a share of total non-aeronautical revenues occurred in 2019 (8.27\%) (Figure $8)$. The largest single annual increase in the annual office and state property rental revenue as a share of total non-aeronautical revenues occurred in 2007, when there was a $50.03 \%$ increase on the previous year's share of total non-aeronautical revenues. The largest single annual decrease in the annual office and state property rental revenue as a share of total non-aeronautical revenues occurred in 2016, when there was a 12.44 $\%$ decrease on the previous year's share of total non-aeronautical revenues (Figure 8). Throughout the period 2005 to 2019 , the annual office and state property rental revenue as a portion of total non-aeronautical revenue averaged around $14.01 \%$. Office and state property rental revenue are AOT's third most significant source of non-aeronautical revenues.

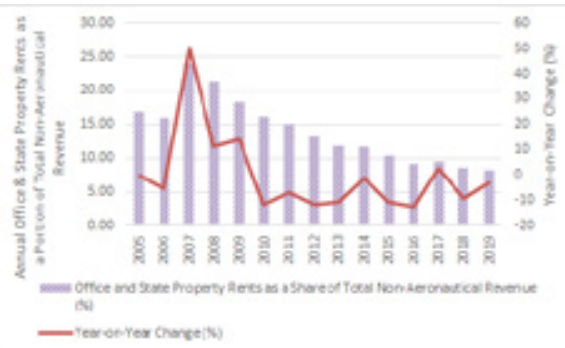

Fig. 8.

Airports of Thailand Public Company Limited Annual Office and State Property Tax Revenues as a Portion of Total non-aeronautical Revenues and Year-on-year Change: 2005-2019

Source: data derived from Airports of Thailand Public Company Limited (2006-2017, 2018b, 2019, 2020) 


\subsection{AOT's Service Revenues}

The Airports of Thailand Public Company Limited has introduced an Advance Passenger Processing System (APPS) at the six airports that it manages and operates. The APPS system enables customs officials, airport and airline staff and immigration police to obtain the profiles of passengers from their countries of origin (Mahitthirook, 2015). AOT assesses a charge for each passenger's use of the advance passenger checking service and AOT's service revenues mainly come from this charge (Airports of Thailand, 2019). The strong growth in AOT's service revenues is exhibited by the year-on-year percentage change line graph, which is more positive than negative, that is, all values except for one are above the line. The only annual single decrease in service revenues was recorded in 2009, when the decreased by $8.31 \%$ on the 2008 levels. This decrease could be attributed to the decline in the annual number of enplaned passengers in 2009. Figure 9 shows that there was a very marked spike in the growth in service revenues in 2007 of $202.18 \%$. Figure 9 also shows that there has been positive year-onyear growth in AOT's service revenues from 2010 to 2019 , which could be attributed to the strong growth in passengers during this period.

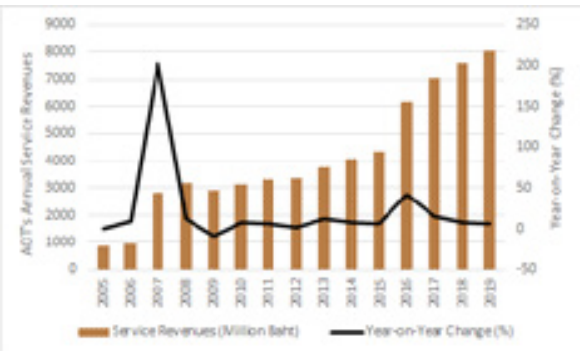

Fig. 9.

Airports of Thailand Public Company Limited Annual Service Revenues and Year-on-year Change: 2005-2019

Source: data derived from Airports of Thailand Public Company Limited (2006-2017, 2018b, 2019, 2020)

AOT's annual service revenue as a portion of total non-aeronautical revenues and the year-on-year change (\%) for the period 2005 to 2019 is presented in Figure 10. As can be observed in Figure 10, AOT's annual service revenue as a portion of total non-aeronautical revenues has fluctuated throughout the period 2005 to 2019. The highest annual share of service revenue as a share of total non-aeronautical revenues was recorded in 2008 (45.56\%), whilst the lowest annual service revenue as a share of total non-aeronautical revenues occurred in 2005 (15.26\%) (Figure 10). The largest single annual increase in the service revenue as a share of total non-aeronautical revenues occurred in 2007 , when there was a $186.31 \%$ increase on the previous year's share of total non-aeronautical revenues. The largest single annual decrease in the annual service revenue as a portion of total aeronautical revenues occurred in 2009, when there was a $31.51 \%$ decrease on the previous year's share of total non-aeronautical revenues (Figure 
10). Throughout the period 2005 to 2019 , the annual service revenue as a portion of total non-aeronautical revenue averaged around
$28.70 \%$. Service revenues are AOT's second most significant source of non-aeronautical revenues.

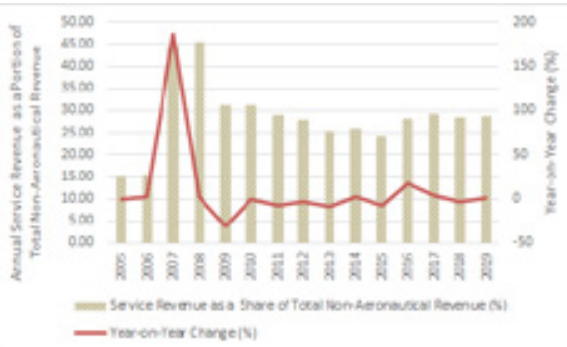

Fig. 10.

Airports of Thailand Public Company Limited Annual Service Revenues as a Portion of Total nonaeronautical Revenues and Year-on-year Change: 2005-2019

Source: data derived from Airports of Thailand Public Company Limited (2006-2017, 2018b, 2019, 2020)

\section{Conclusion}

This study has examined, for the first time, the development in and types of nonaeronautical revenue sources of Airports of Thailand PLC (AOT) from 2005 to 2019. The study used a qualitative longitudinal research design. The data collected for the study was examined using document analysis. The qualitative case study was supported by the case study research framework that followed the guidelines recommended by Yin (2018).

Like other airports around the world, the Airports of Thailand PLC (AOT) earns its revenue from both the provision of aeronautical services and infrastructure and from non-aeronautical services. The aeronautical revenues are comprised of aircraft service charges, departure passenger service charges, and landing and parking charges. The non-aeronautical revenues are comprised of concession revenues, office and state property rents, and service revenues.
The case study revealed that the Airports of Thailand PLC (AOT) non-aeronautical revenues have grown significantly throughout the study period. Nonaeronautical revenues have averaged around forty per cent of the company's annual revenues. The most significant growth in Airports of Thailand revenues occurred in non-aeronautical revenues which increased by $392.92 \%$ over the study period.

The Airports of Thailand PLC (AOT) three non-aeronautical revenue sources all grew strongly over the study period. The most significant growth was recorded in service charge revenue $(+831.82 \%)$, followed by concession revenue $(+357.05 \%)$, and office and state property rents $(+140.93 \%)$. The strong growth in passenger volumes underpinned the substantial increases in the company's non-aeronautical revenues.

\section{References}

Abeyratne, R. 2009. Airport business law. Author House, Bloomington, USA. 284 p. 
Abeyratne, R. 2014. Convention on international civil aviation: A commentary. Springer International Publishing, Switzerland. 737 p.

Airports Council International. 2012. Guide to airport performance measures. Airports Council International, Canada, $61 \mathrm{p}$.

Airports of Thailand PLC. 2006. Annual report 2005. Available from Internet: <http://aot.listedcompany. com/misc/AR/AR2005.pdf $>$.

Airports of Thailand PLC. 2007. Annual report 2006. Available from Internet: <http://aot.listedcompany. com/misc/AR/aot_ar2006.pdf $>$.

Airports of Thailand PLC. 2008. Annual report 2007. Available from Internet: <http://aot.listedcompany. com/misc/AR/aot_ar2007.pdf $>$.

Airports of Thailand PLC. 2009. Annual report 2008 . Available from Internet: $<$ http: //\%3 A \% 2 f $\% 2$ Faotlistedcompany. com\%2Fmisc\%2FAFaot_ar2008.pdf $>$.

Airports of Thailand PLC. 2010. Making connections: Annual report 2009. Available from Internet: <http:// aot.listedcompany.com/misc/AR/ar2009_en.pdf $>$.

Airports of Thailand PLC. 2011. Beyond connections: Annual report 2010. Available from Internet: <http:// aot.listedcompany.com/misc/AR/ar2010_en.pdf $>$.

Airports of Thailand PLC. 2012. Annual report 2011: Green airport. Available from Internet: <http://aot. listedcompany.com/misc/AR/20120508-AOR-AR2011EN.pdf $>$.

Airports of Thailand PLC. 2013. The global gateway: Annual report 2012. Available from Internet: <http:// aot.listedcompany.com/misc/AR/20120508-AORAR2011-EN.pdf>.
Airports of Thailand PLC. 2014. Annual report 2013. Available from Internet: <http://aot.listedcompany. $\mathrm{com} / \mathrm{misc} / \mathrm{AR} / 20140121-A O T-A R 2013-E N$.pdf $>$.

Airports of Thailand PLC. 2015. Annual report 2014. Available from Internet: <http://aot.listedcompany. com/misc/AR/20150122-aot-ar2014-en.pdf>.

Airports of Thailand PLC. 2016. Prepare for takeoff: Annual report 2015. Available from Internet: <http:// aot.listedcompany.com/misc/AR/20160112-aot-ar2015-en.pdf $>$.

Airports of Thailand PLC. 2017. To the sky: Annual report 2016. Available from Internet: $<$ http: //\%3 A \% 2 F \% 2 Fa ot listedcompany. com\%2Fmisc\%2FAR\%2F20170412-aot-ar-2016-en. pdf $>$.

Airports of Thailand PLC. 2018a. About AOT: Business characters. Available from Internet: <https://www. airportthai.co.th/en/airports-of-thailand-plc/aboutaot/business-characters/ $>$.

Airports of Thailand PLC. 2018b. Beyond the boundary: annual report 2017. Available from Internet: <http://\%3A\%2F\%2Faotlistedcompany. com\%2Fmisc\%2FAR\%2F20180103-aot-ar-2017-en. pdf $>$.

Airports of Thailand PLC. 2019. To meet our targets: Annual report 2018. Available from Internet: <http://\%3A\%2F\%2Faotlistedcompany. com\%2Fmisc\%2FAR\%2F20190108-aot-ar-2018-en. pdf $>$.

Airports of Thailand PLC. 2020. Inspiring the world with smartest airports: Annual report 2019. Available from Internet: <http://\%3A\%2F\%2Faotlistedcompany. com\%2Fmisc\%2FAR\%2F20200109-aot-ar-2019-en. pdf $>$.

\section{ijtte 609}


Asian Development Bank. 2014. A comparative infrastructure development assessment of the Republic of South Korea and the Kingdom of Thailand. Asian Development Bank, Philippines. 58 p.

Baxter, G. 2020. Sustainable airline waste management: A case study of Air New Zealand's waste management programs and strategies, International Journal for Traffic and Transport Engineering 10(3): 351 - 370.

Betancor, O.; Rendeiro, R. 2000. Airports. In book (eds. Estache, A., de Rus, G.) Privatization and Regulation of Transport Infrastructure: Guidelines for Policymakers and Regulators. The World Bank, USA, 51-111.

Castro, R.; Lohmann, G. 2014. Airport branding: Content analysis of vision statements, Research in Transportation Business \& Management 10: 4-14.

Derrington, M.L. 2019. Qualitative longitudinal methods: Researching implementation and change. SAGE Publications, USA. 128 p.

Doganis, R. 2005. The airport business. Routledge, UK. 244 p.

Forsyth, P.; Müller, J.; Niemeier, H.M. 2016. Airport, structure, and performance: A review. In book (eds. Finger, M., Jaag, C.) The Routledge Companion to Network Industries. Routledge, UK, 360-375.

Fasone, V.; Kofler, L.; Scuderi, R. 2016. Business performance of airports: Non-aviation revenues and their determinants, Journal of Air Transport Management 53: $35-45$.

Freestone, R. 2009. Planning, sustainability and airportled urban development, International Planning Studies 14(2): 161-176.
Fu, X., Yang, H. 2013. Airport - airline arrangements: An interpretative view of industry practices and recent studies. In book (eds. Peoples, J. D., Bitzan, J.H.) The Economics of Airport Operations. Emerald Group Publishing, UK, 97-123.

Graham, A. 2009. How important are commercial revenues to today's airports? Journal of Air Transport Management 15(3): 106-111.

Graham, A.; Morrell, P. 2017. Airportfinance and investment in the global economy. Routledge, UK. 238 p.

Halpern, N.; Graham, A. 2013. Airport marketing. Routledge, UK. 154 p.

Hassett, M.; Paavilainen-Mäntymäki, E. 2013. Longitudinal research in organizations: An introduction. In book (eds. Hasset. M., PaavilainenMäntymäki, E.) Handbook of Longitudinal Research Methods in Organisation and Business Studies. Edward Elgar Publishing, UK, 1-22.

Holloway, S. 2016. Straight and level: practical airline economics, Third Edition. Routledge, UK. 616 p.

International Civil Aviation Organization. 2013a. Airport economics manual. Third Edition. ICAO, Canada. 152 p.

International Civil Aviation Organization. 2013b. Case study on commercialization, privatization and economic oversight of airports and air navigation services providers: Thailand. Available from Internet: <https://www.icao.int/sustainability/CaseStudies/ Thailand.pdf $>$.

Janić, M. 2016. The sustainability of air transportation - A quantitative analysis and assessment. Routledge, UK. 376 p. 
Jiminez, E.; Claro, J.; Pinho de Sousa, J. 2014. The airport business in a competitive environment, Procedia - Social and Behavioral Sciences 111: 947-954.

Jupp, V. 2006. The SAGE dictionary of research methods. SAGE Publications, USA. 353 p.

Lei, Z.; Pagliari, R. 2016. Airport traffic growth and airport financial performance. In book (eds. Forsyth et al.) Liberalization in Aviation: Competition, Cooperation, and Public Policy. Routledge, UK, 287-298.

Liu, D. 2016. Measuring aeronautical service efficiency and commercial service efficiency of East Asia airport companies: An application of network data envelopment analysis, Journal of Air Transport Management 52: 11-22.

Lyon, D.; Francis, G. 2014. Current issues in airport management in New Zealand. In book (ed. Duval, D.T.) Air Transport in the Asia Pacific. Routledge, UK, 53-72.

Mahitthirook, A. 2015. Air passengers face extra 35B security fee. Available from Internet: <https://www. bangkokpost.com/thailand/general/641452/airpassengers-face-extra-35b-security-fee $>$.

Moh, Z.C.; Lin, P. 2005. Case study of ground improvement work at the Suvarnabhumi Airport of Thailand. In book (eds. Indraratna, B., Chu, J.) Ground Improvement: Case Histories. Elsevier, The Netherlands, 159-198.

Moulds, J.; Lohmann, G. 2016. An analysis of future trends in non-aeronautical revenue: A case study from Adelaide Airport, Journal of Airport Management 10(4): 343-358.

Neale, B. 2018. What is qualitative longitudinal research? Bloomsbury Publishing, UK. 176 p.

Oates, B.J. 2006. Researching information systems and computing. SAGE Publications, UK. 360 p.
O'Leary, Z. 2004. The essential guide to doing research. SAGE Publications, UK. 226 p.

Orth, H.; Frei, O.; Weidmann, U. 2015. Effects of nonaeronautical activities at airports on the public transport access system: A case study of Zurich Airport, Journal of Air Transport Management 42: 37-46.

Rahim, A. R.; Baksh, M. S. 2003. Case study method for new product development in engineer-to-order organisations, Work Study 52(1): 25-36.

Ramon Gil-Garcia, J. 2012. Enacting electronic government success: An integrative study of government-wide websites, organizational capabilities, and institutions. Springer Science-Business Media, USA. 254 p.

Reiss, B. 2007. Maximising non-aviation revenue for airports: Developing airport cities to optimise real estate and capitalise on land development opportunities, Journal of Airport Management 1(3): 284-293.

Scott, J. 2014. A dictionary of sociology. Fourth Edition. Oxford University Press, UK. 848 p.

Scott, J.; Marshall, G. 2009. A dictionary of sociology. Third Edition. Oxford University Press, USA. 815 p.

Senguttuvan, P.S. 2007. Principles of airport economics. Excel Books, India. 464 p.

Serebrisky, T. 2012. Airport economics in Latin America and the Caribbean: Benchmarking, regulation, and pricing. The World Bank, USA. 278 p.

Stebbins, R.A. 2001. Exploratory research in the social sciences. SAGE Publications, USA. 67 p.

Vogel, H.A. 2019. Foundations of airport economics and finance. Elsevier, The Netherlands. 330 p. 
Wattanacharoensil, W.; Schuckert, M.; Graham, A.; Dean, A. 2017. An analysis of the airport experience from an air traveler perspective, Journal of Hospitality and Tourism Management 32: 124-135.

Yin, R.K. 2018. Case study research and applications. Sixth Edition, SAGE Publications, USA. 352 p.

Yokomi, M.; Wheat, P.; Mizutani, J. 2017. The impact of low-cost carriers on non-aeronautical revenues in airport: An empirical study of UK airports, Journal of Air Transport Management 64 (Part A): 77-85.
Young, S.B.; Wells, A.T. 2011. Airport planning and management. Sixth Edition. McGraw-Hill, USA. 588 p.

Zhang, A.; Zhang, Y. 1997. Concession revenue and optimal airport pricing, Transportation Research Part E: Logistics and Transportation Review 33(4): 287-296.

Zhang, A.; Fu, X.; Yang, H. 2010. Revenue sharing with multiple airlines and airports, Transportation Research Part A: Methodological 44(8-9): 944-959. 